\title{
Mapping deforestation and forest degradation using CLASlite approach in Eastern Churia of Nepal
}

\begin{abstract}
S. Khanal ${ }^{1 *}$ and A. Khadka ${ }^{1}$
Monitoring deforestation and forest degradation is essential for forest conservation and sustainable management. Those activities have become more relevant in order to get reference emission level required for Reducing emissions from deforestation and forest degradation (REDD) initiative. The study aimed to assess forest degradation and deforestation in the Churia region of Eastern Nepal using CLASlite approach. This approach is based on Spectral Mixture Analysis and provides highly automated technique for forest cover, deforestation and forest degradation mapping. The Landsat imageries of 2002 and 2013 were processed for estimation of deforestation and forest degradation. The validation of results based on the high-resolution multi-temporal Google Earth imageries and the field sample plots indicated that CLASlite approach could be feasible approach to monitor forests for deforestation and degradation. The results can be further improved by including more frequent time-series observation from Landsat.
\end{abstract}

Key words: Churia, CLASlite, deforestation, forest degradation, spectral mixture analysis

$\mathrm{T}$ The importance of forest resources has been well understood because of their important services to the society such as supporting rural livelihood, carbon storage, climate change mitigation, and biodiversity conservation. The issue of forest conservation is more directly relevant in the case of Nepal, as forest resources are significant for ecosystem balance and people's livelihood (Birch et al., 2014). Further, because of pertinent issue of deforestation and degradation (Panta et al., 2008) timely monitoring forest resources is very essential. Successful design and implementation of programs to reduce emissions from deforestation and forest degradation and promote reforestation (REDD+) would require periodic monitoring of deforestation and forest degradation (Goetz et al., 2015; Herold and Johns, 2007).

Nepal is divided into five physiographic regions: High Himalaya, High Mountain, Middle Mountain, Siwaliks or Churia and Terai (LRMP, 1986). Churia is a belt of hilly region stretching from East to West in the entire length of Southern Nepal. This region is ecologically diverse, and as it provides several ecosystem services to the areas downstream, it has direct influence on the quality of the environment. However, the Churia Hills are structurally weak (Khanal, 1989) since this area is the youngest mountain range in the Himalayas and have high potential of erosion hazards. The significance of Churia conservation has been highlighted for quite some time. For instance, Gurung and Khanal (1986) reported the significant land use change in Churia, and recommended for detailed study of forestry among other sectors. According to the latest forest resource assessment (2010-2014) results, this region has $73.0 \%(1,384,445 \mathrm{ha})$ of the total area under forests; majority of the forest area $(76 \%)$ falling outside the protected areas with the annual rate of forest cover change of $-0.21 \%$ between the period 2001-2010 (DFRS, 2014).

Till now, much focus has been given to quantify and monitor deforestation, but the understanding as well as mapping of spatial distribution of forest degradation has remained far behind. Furthermore, for deforestation monitoring, several standard methods have been tested and are available for user community. However, getting reliable estimates of forest degradation remains a challenge (DeFries et al., 2007). Forest degradation is generically defined as the "reduced capacity of a forest to provide goods and services" (FAO, 2002). Some major causes of forest degradation can be one or the combination of processes such as selective logging, conversion

\footnotetext{
Department of Forest Research and Survey, Kathmandu, Nepal.*E-mail: skhanal@dfrs.gov.np
} 
of land cover and natural disturbances (such as landslide, fire, flood etc.). Thus, the time-scale of processes leading to forest degradation can range from few years to a few decades. Grainger (1993) has defined forest degradation as a process leading to a "temporary or permanent deterioration in the density or structure of vegetation cover or its species composition". The ultimate consequence of degradation is, therefore, reduced productivity of forests due to impact of disturbances. Reduction in the canopy cover is observed to indicate forest degradation while the estimates of forest canopy cover is estimated on the basis of remotely sensed observations (Wang et al., 2005; Souza et al., 2003).

This study was conducted under the broad theme of the Department of Forest Research and Survey (DFRS) to map and monitor Nepal's forests with advanced forest monitoring technology. Given the challenges associated with mapping forest degradation, it is very essential to validate and apply the available forest degradation and deforestation monitoring approaches. The outcome of such studies has a high relevance to decide on the robust approach that can be applied for other parts of Nepal and also to integrate forest assessment systems for periodic monitoring of deforestation and forest degradation. CLASlite has been demonstrated as an applicable tool to support REDD+ initiative for reliable forest cover estimation in order to support sub-national to national reference levels (Reimer et al., 2015). However, most of the studies on applicability of CLASlite approach has been conducted on ecosystems much different than in Nepal (Allnutt et al. 2013; Bryan et al. 2013; Carlson et al. 2012). This study examined the applicability of CLASlite approach for assessment of deforestation and forest degradation in Nepal's Churia forest.

\section{Materials and methods}

\section{Study area}

The study area encompasses the Churia in the Eastern Development Region (EDR) of Nepal (Fig. 1). The major portions of the Churia belt in the EDR are located in Siraha, Udayapur, Saptari, Sunsari, Morang, Dhankuta, Jhapa and Ilam districts.

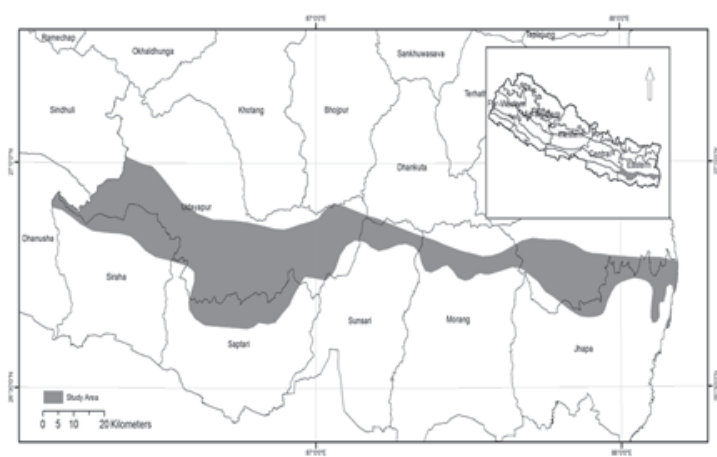

Fig. 1: Map showing the Churia in the Eastern Development Region of Nepal

\section{Method for forest degradation monitoring}

Different methods have been tried for forest degradation monitoring ranging from use of LiDAR (Jubanski et al., 2013), RADAR (Ryan et al., 2012) and Landsat time series analysis (Healey et al., 2005).

The Spectral Mixture Analysis (SMA) approach has been developed to extract information at sub-pixel level. It decomposes mixed pixels into fractions of end-members, and has been proposed to overcome the mixed pixel problem found in degraded forests (Souza et al., 2003). The SMA approach (Equation 1) has been applied with SPOT Satellite data (Souza et al., 2003) and Landsat data (Asner et al., 2005; Souza et al., 2005; Negron-Juarez et al., 2011) with varying success for purposes ranging from canopy gap detection and biomass estimation to delineation of logged areas.

$$
R_{b}=\sum_{i=1}^{n} f_{i} R_{i, b}+e_{b}
$$

Where,

$\mathrm{R}_{\mathrm{b}}=$ Reflectance for each band $\mathrm{b}$ in the image,

$\mathrm{N}=$ No. of end-members,

$f_{i} \quad=$ Fraction of end member "i",

$\mathrm{R}_{\mathrm{i}}, \mathrm{b}=$ Reflectance of end-member " $\mathrm{i}$ " in band $\mathrm{b}$, and

$\mathrm{e}_{\mathrm{b}} \quad=$ Unmodeled residual.

Souza et al. (2005) developed Normalized Difference Fraction Index (NDFI) to combine the information from SMA significant for forest degradation monitoring into one band, and attained $94 \%$ accuracy in detecting forest areas with canopy damage. Intact forests have high NDFI values because of higher green vegetation while non-photosynthetic vegetation as well as soil fraction increase as forests are degraded, and thus NDFI values become lower. 
One of the tools that support the implementation of SMA is CLASlite program. It includes a set of tools that automate radiometric correction and use Monte Carlo Unmixing (MCU) to produce estimates of the percentage cover of soil, photosynthetic vegetation (PV), and nonphotosynthetic vegetation (NPV) in every image pixel (Asner et al., 2009). Thus, the output raster would have three fractional cover classes:

i) Photosynthetic vegetation (PV) i.e. Live vegetation ii) Non-photosynthetic vegetation (NPV) i.e. Dead or senescent vegetation and iii) Bare substrate (S) i.e. Soil. We used CLASlite version 3.2 package (CLASlite Team, 2014) for the purpose of our study. Default threshold values were used for the estimation of forest as well as detection of forest cover loss (deforestation) and degradation (areas of persistent forest disturbance).

\section{Datasets used}

Landsat images were selected in two time periods for detecting deforestation and forest degradation. The available scenes were filtered to be within close months and have the least cloud cover as much as possible. The details on the Landsat scenes used in the analysis are presented in Table 1 , while the footprints of those scenes are shown in Fig. 2.

The resulting deforestation and degradation outputs were generalized by filtering the pixel groups that were less than 0.5 hectare. This was done in order to avoid the scattered pixels and also to identify larger areas that underwent through changes so that the implementation agencies could identify the areas requiring restoration interventions with the help of the outputs obtained.

Table 1: Details on the Landsat images used

\begin{tabular}{llccr}
\hline Satellite & Sensor & $\begin{array}{c}\text { Path- } \\
\text { Row }\end{array}$ & Date & $\begin{array}{r}\text { Cloud } \\
\text { Cover }\end{array}$ \\
\hline Landsat 7 & ETM+ & $139-041$ & $2002-12-16$ & 8.62 \\
& & $140-041$ & $2002-12-23$ & 3.88 \\
Landsat 8 & \multirow{2}{*}{ OLI /TIRS } & $139-041$ & $2013-12-06$ & 5.86 \\
& & $140-041$ & $2013-11-11$ & 5.22 \\
\hline
\end{tabular}

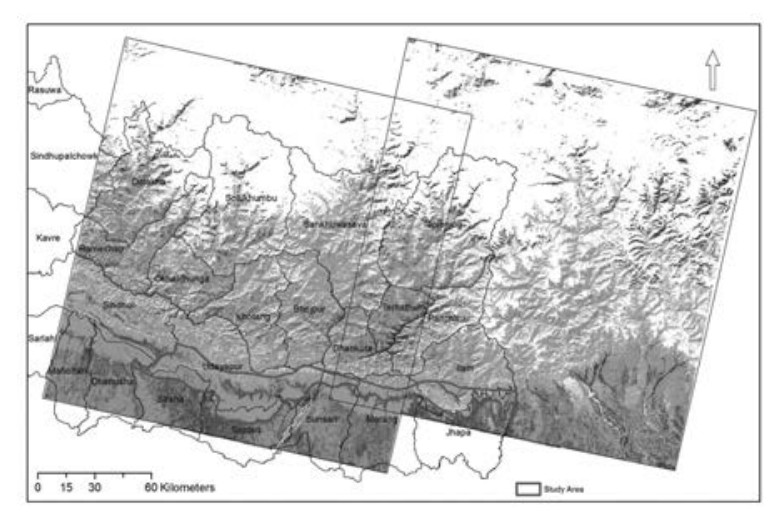

Fig. 2: Footprint of Landsat scenes over the study area. The images shown are fractional cover derived from Landsat 8 of 2013

\section{Results and discussion}

The outputs from the analysis provided the map of the areas that had deforestation and forest degradation between 2002-2013 (Fig. 3).

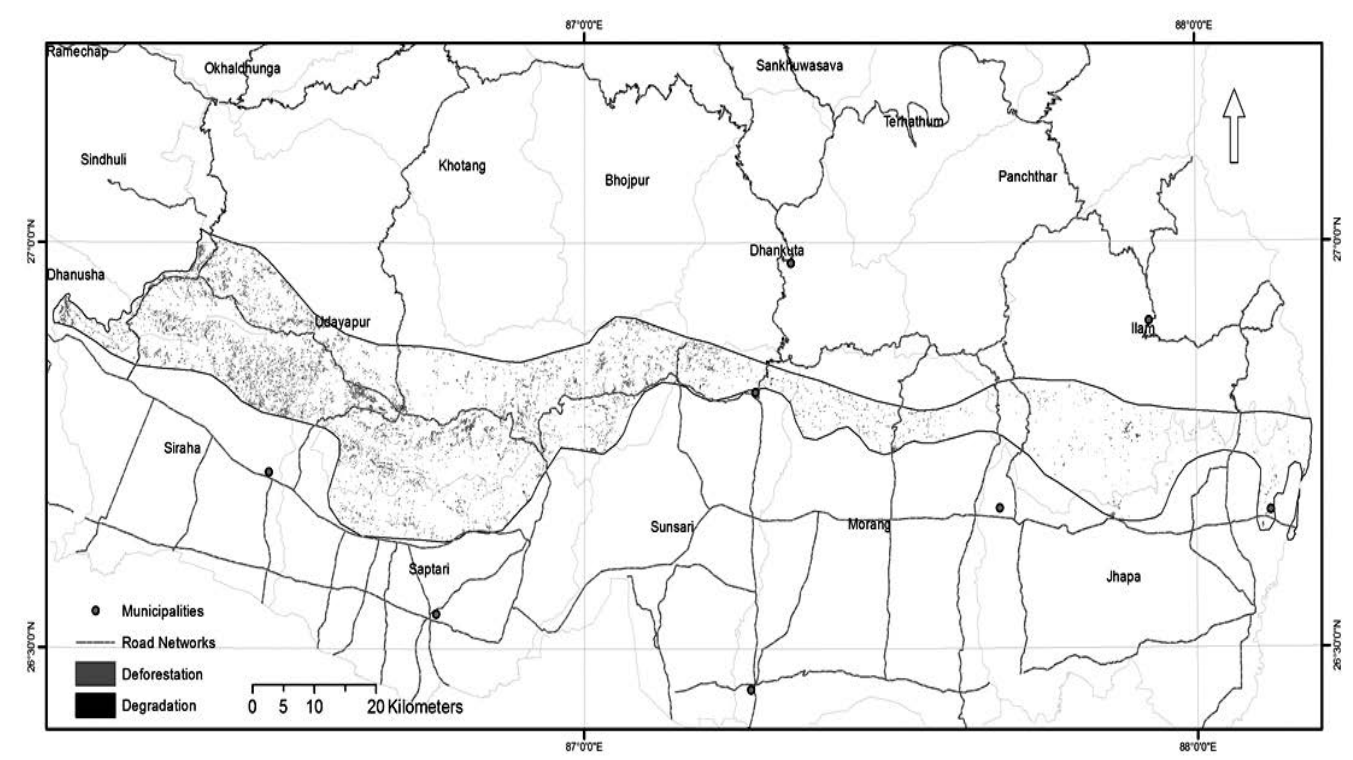

Fig. 3: Map showing the deforested and degraded areas in the studied Churia region between 2002-2013 
The district-wise area of deforestation and degradation in the Churia region was calculated. For comparison, the data from Hansen et al. (2013) was used which has analyzed time series Landsat images to estimate global-level forest extent and change from 2000 to 2013. The result for the study area extent is presented in the Table 2 , so as to make general comparison. The last column is the deforestation estimated based on Hansen et al., 2013. However, it is important to note that the analysis was done at global scale, and thus requires local-level validation. Udayapur district was found to have the highest area of deforestation and forest degradation (Table 2).

Table 2: District-wise area of forest degradation and deforestation estimated

\begin{tabular}{lcrc}
\hline District & $\begin{array}{c}\text { Deforestation } \\
\text { (ha) }\end{array}$ & $\begin{array}{r}\text { Degradation } \\
\text { (ha) }\end{array}$ & $\begin{array}{r}\text { Deforestation } \\
\text { (ha) (Hansen } \\
\text { et al. 2013) }\end{array}$ \\
\hline Dhankuta & 27.36 & 17.01 & 1.44 \\
Ilam & 95.22 & 111.51 & 137.07 \\
Jhapa & 28.71 & 61.47 & 36.81 \\
Morang & 28.35 & 228.15 & 36.09 \\
Saptari & 242.64 & 254.61 & 352.35 \\
Siraha & 921.33 & 500.31 & 412.83 \\
Sunsari & 96.39 & 171.54 & 13.68 \\
Udayapur & $2,904.48$ & $1,420.11$ & 680.31 \\
\hline
\end{tabular}

The degradation and deforestation map produced was validated in the field using 40 sample sites. Those plots were generated randomly over the detected deforestation and degradation sites. The deforested areas were also cross-examined using the available high-resolution multi-temporal imageries. Several examples of interesting observations of deforestation were made. One of the examples is presented in Figure 4. The forest cover loss was more clearly detected (Fig. $5 a, b, c)$ as compared to the forest degradation as it required more field observation to identify why a certain pixel was recorded under the category of degraded areas. The observations indicated that the areas identified as degraded had some major characteristics of disturbance such as the areas with lopped-trees, the areas with selective logging and the areas covered by dense invasive shrubs (Fig. 5a,b,c). Some natural disturbances on those sites included landslide, fire impact and river deposition.
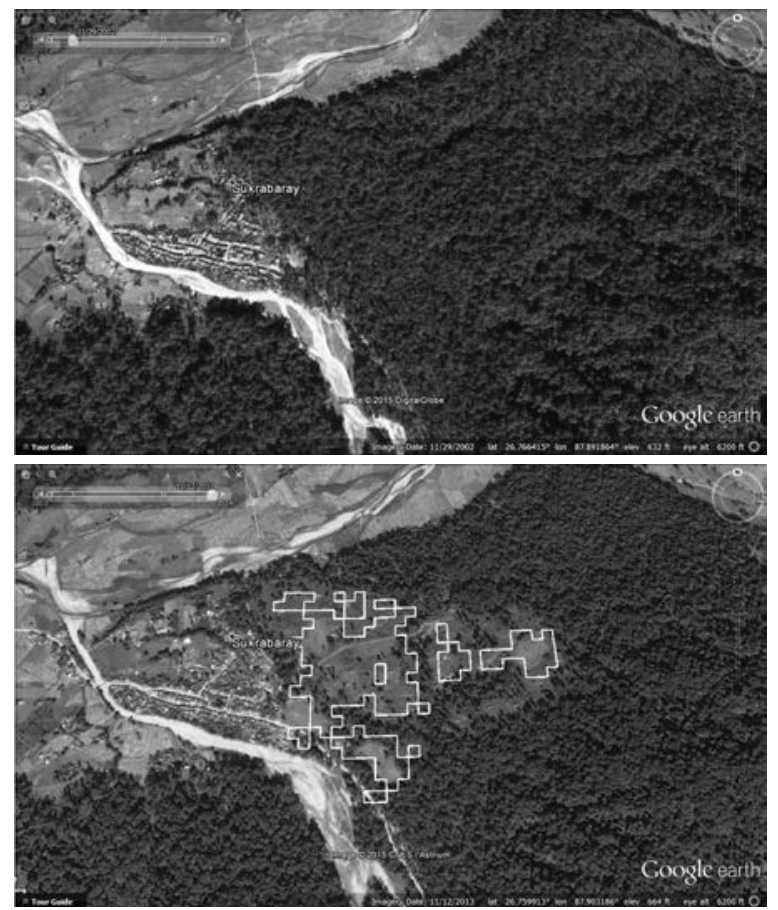

Fig. 4: Example of a deforestation site mapped in Sukrebaray area of Jhapa District on the Google Image of Nov 2002 (upper panel) and Dec 2013 (lower panel). The polygon with white boundary in the lower panel shows the mapped deforested area.

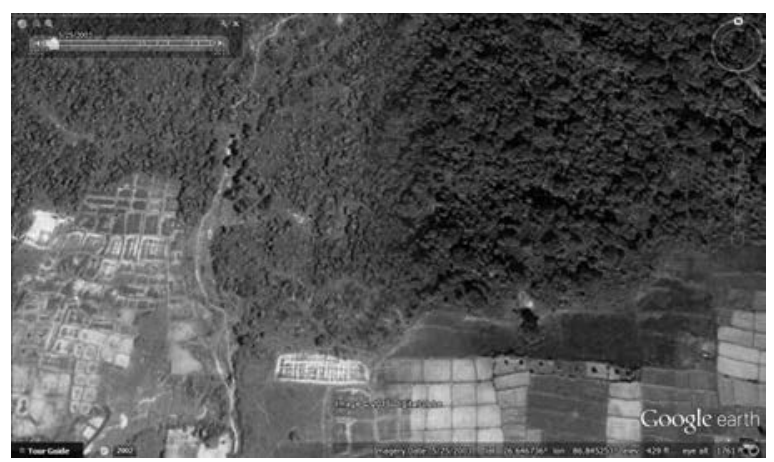

Fig. 5a

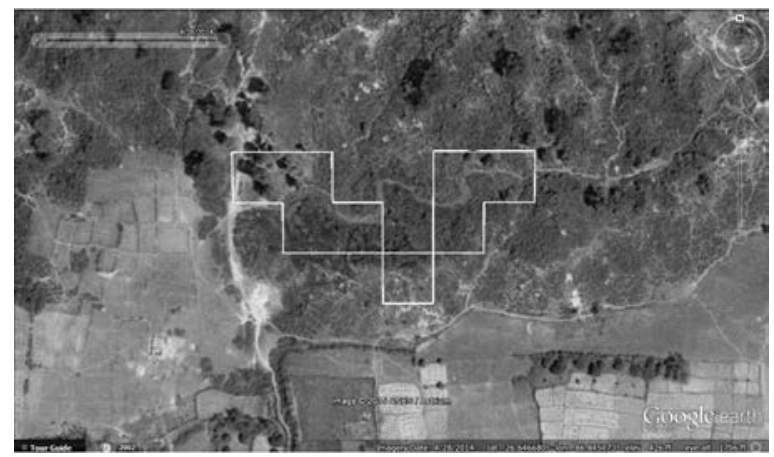

Fig. 5b 


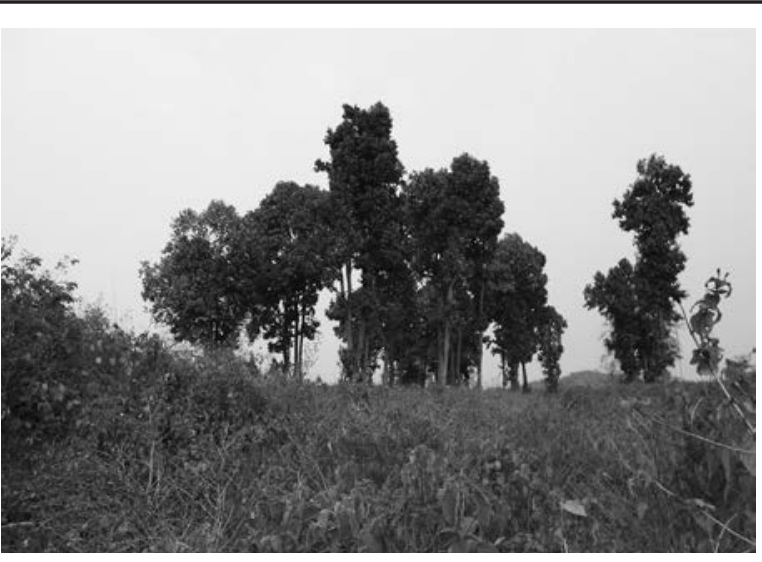

Fig. 5c

Fig. 5a,b,c: Degraded forest observed at the North of Bengari in Saptari District. The area in the Fig. 5b (Apr, 2014) and the white polygons show the mapped degraded sites since May, 2003 (Fig. 5a). Field observation indicated trees removed and the area covered with dense invasive shrubs (Fig. 5c).

Spectral libraries derived from extensive field databases and satellite imageries have been used to represent tropical forests ranging from lowlands to mountain ecosystems in the newer version of the CLASlite Software Package (CLASlite Team, 2014). This could be the reason behind the interesting performance of the package in spite of being originally developed for different ecosystem than a mountainous country like Nepal. However, future studies should test and identify proper threshold of parameters and select the best ones based on the validation results. Further, there are always challenges associated with shadows in the case of a mountainous country like Nepal. These issues can be potentially addressed through more frequent time-series observations of cloud-free satellite imageries.

\section{Conclusion}

The findings from this study indicate that CLASlite-based analysis can be one potential approach to monitor forests for deforestation and forest degradation. In this study, some areas that underwent through such changes could not be accounted for due to the lack of information induced by clouds and shadows in the mountainous regions. This issue can be possibly minimized by incorporating cloud-free image composites. However based on validation with high-resolution multi-temporal Google Earth Imageries and as observed in some interesting examples of changes, the approach seems to be promising and would need further in-depth analysis. The results can be potentially further improved by including more frequent time-series observations which are becoming more practical option with the availability of newer images including Landsat. The information generated through this study are expected to be useful for identifying the deforested areas and or degraded forest areas on the one hand and for identifying the areas to be reforested or planted on the other hand.

\section{References}

Allnutt, T. F., Asner, G. P., Golden, C. D. and Powell, G. V. 2013. Mapping recent deforestation and forest disturbance in north eastern Madagascar. Tropical Conservation Science 6 (1): 1-15.

Asner, G. P., Knapp, D. E., Cooper, A. N., Bustamante, M. M., and Olander, L. P. 2005. Ecosystem structure throughout the Brazilian Amazon from Landsat observations and automated spectral unmixing. Earth Interactions 9 (7): 1-31.

Asner, G. P., Knapp, D. E., Balaji, A., and PáezAcosta, G. 2009. Automated mapping of tropical deforestation and forest degradation: CLASlite. Journal of Applied Remote Sensing 3 (1): 033543.

Birch, J. C., Thapa, I., Balmford, A., Bradbury, R. B., Brown, C., Butchart, S. H., Gurung, H., Hughes, F. M., Mulligan, M., Pandeya, B. and Peh, K. S. H. 2014. What benefits do community forests provide, and to whom? A rapid assessment of ecosystem services from a Himalayan forest, Nepal. Ecosystem Services 8: 118-127.

Bryan, J. E., Shearman, P. L., Asner, G. P., Knapp, D. E., Aoro, G., and Lokes, B. 2013. Extreme differences in forest degradation in Borneo: comparing practices in Sarawak, Sabah, and Brunei. PloS One 8 (7): e69679.

Carlson, K. M., Curran, L. M., Ratnasari, D., Pittman, A. M., Soares-Filho, B. S., Asner, G. P., Trigg, S. N., Gaveau, D. A., Lawrence, D. and Rodrigues, H. O. 2012. Committed carbon emissions, deforestation, and community land conversion from oil palm 
plantation expansion in West Kalimantan, Indonesia. In Proceedings of the National Academy of Sciences 109 (19): 7559-7564.

CLASlite Team, 2014. CLASlite Forest Monitoring Technology: Version 3.2 User Guide. Carnegie Institution for Science, Stanford, CA. http://claslite.carnegiescience. edu accessed on 23 Dec, 2015.

DeFries, R., Achard, F., Brown, S., Herold, M., Murdiyarso, D., Schlamadinger, B., and de Souza, C. 2007. Earth observations for estimating greenhouse gas emissions from deforestation in developing countries. Environmental Science and Policy 10 (4): 385-394.

DFRS. 2014. Churia Forests of Nepal. Forest Resources Assessment Nepal Project, Department of Forest Research and Survey (DFRS), Kathmandu, Nepal.

FAO. 2002. Proceedings: Second Expert Meeting on Harmonizing Forest-related Definitions for Use by Various Stakeholders. 11-13 September 2002, Rome. http://www.fao.org/ docrep/005/y4171e/y4171e00.htm accessed on 23 Dec, 2015.

Goetz, S., Hansen, M., Houghton, R. A., Walker, W., Laporte, N. T. and Busch, J. 2015. Measurement and Monitoring for REDD+: The Needs, Current Technological Capabilities, and Future Potential. Center for Global Development Working Paper, 392.

Grainger, A. 1993. Controlling Tropical Deforestation. Earthscan Publications, London, UK.

Gurung, H. and Khanal, N. 1986. Landscape processes in the Chure Range Central Nepal. Himalayan Review 17: 1-39.

Hansen, M. C., Potapov, P. V., Moore, R., Hancher, M., Turubanova, S. A., Tyukavina, A., Thau, D., Stehman, S. V., Goetz, S. J., Loveland, T. R., Kommareddy, A., Egorov, A., Chini, L., Justice, C. O. and Townshend, J. R. G. 2013. High-resolution global maps of $21^{\text {st }}$-century forest cover change. Science 342: 850-853.

Healey, S. P., Cohen, W. B., Zhiqiang, Y. and
Krankina, O. N., 2005. Comparison of Tasseled Cap-based Landsat data structures for use in forest disturbance detection. Remote Sensing of Environment 97 (3): 301-310.

Herold, M. and Johns, T. 2007. Linking requirements with capabilities for deforestation monitoring in the context of the UNFCCC-REDD process. Environmental Research Letters 2 (4): 045025.

Jubanski, J., Ballhorn, U., Kronseder, K., Franke, J. and Siegert, F. 2013. Detection of large above-ground biomass variability in lowland forest ecosystems by airborne LiDAR. Biogeosciences 10: 3917-3930.

Khanal, N.R. 1989. Morphometric properties of the drainage basins in the Chure range, Nepal. Himalayan Review 20: 59-65.

LRMP. 1986. Land System Report. Land Resource Mapping Project (LRMP): Kenting Earth Science, Canada.

Negron-Juarez, R. I., Chambers, J. Q., Marra, D. M., Ribeiro, G. H. P. M., Rifai, S. W., Higuchi, N. and Roberts, D. 2011. Detection of subpixel treefall gaps with Landsat imagery in Central Amazon forests. Remote Sensing of Environment 115: 3322-3328.

Panta, M., Kim, K. and Joshi, C. 2008. Temporal mapping of deforestation and forest degradation in Nepal: applications to forest conservation. Forest Ecology and Management 256 (9): 1587-1595.

Reimer, F., Asner, G. P., and Joseph, S. 2015. Advancing reference emission levels in subnational and national REDD+ initiatives: a CLASlite approach. Carbon Balance and Management 10 (5). doi: 10.1186/s13021015-0015-8.

Ryan, C. M., Hill, T., Woollen, E., Ghee, C., Mitchard, E., Cassells, G., Grace, J., Woodhouse, I. H. and Williams, M. 2012. Quantifying small-scale deforestation and forest degradation in African woodlands using radar imagery. Global Change Biology 18 (1): 243-257.

Souza Jr., C., Firestone, L., Silva, M. L., Roberts 
and D.A. 2003. Mapping forest degradation in the Eastern Amazon from SPOT 4 through spectral mixture models. Remote Sensing of Environment 87: 494-506.

Souza Jr., C., Roberts, D. A. and Cochrane, M. A. 2005. Combining spectral and spatial information to map canopy damage from selective logging and forest fires. Remote
Sensing of Environment 98: 329-343.

Wang, C., Qi, J., and Cochrane, M. 2005. Assessment of tropical forest degradation with canopy fractional cover from Landsat ETM+ and IKONOS imagery. Earth Interactions 9 (22): 1-18. 